\section{German Physical Society: AKO-Workgroup}

The "Workgroup on future opportunities" (Arbeitskreis Optionen für die Zukunft - AKO) is a committee of the German Physical Society (DPG) for improving young physicists' perspectives. The poor job-market situation for physicists in Germany was the underlying reason for the initiative.

Founded in 1994, the Workgroup presented its first activities to a wider audience at the DPG conference in Spring 1995.

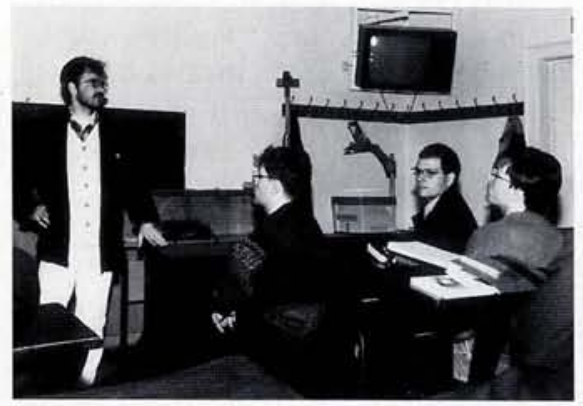

Photo: E. Dreisigacker

The AKO is by far the "youngest" committee of the DPG and an openstructured, multilevel group. Members come from all those areas really concerned with the actual physics job-market situation: students, graduates, postdocs., young founders, employed physicists, professors and industrial representatives. The constitution guarantees a competent partner within the committee to initialize activities in different regions of interest, described below. To ensure a high level of continuity and flexibility, the Workgroup meets about six times a year. The main regions of interest encompass the following topics:

\section{Practical assistance}

- At DPG conferences, panel discussions and poster sessions are organized. Members of the Workgroup present their activities. In addition, invited speakers, from industry for example, give talks to illustrate their perspectives.

Subsequently, open discussions involving the audience take place.

- Members of the workgroup organize various seminars. So far two seminars for young founders and one for job-applicants have been held. These seminars are announced in the DPG monthly magazine Physikalische Blätter, and any DPG member may apply to attend. All stages of the organization are discussed at the AKO meetings. Feedback from the participants is an integral part of the discussion that summarizes the outcome of the seminars,

\section{List of job-applicants}

Since March 1995 a list of jobapplicants appears in Physikalische Blätter. The list can also be accessed by WWW and presents the profiles of those DPG members who have submitted their data to the DPG. This service is free of charge. If an employer wishes to know more about a certain candidate, direct contact is established. The objectives and application of the list are regularly reviewed by the AKO to improve its practicability.

\section{Public relations}

- A short informative brochure has been designed and printed. This folder targets Small and Medium-sized Enterprises (SMEs). It presents information on the capabilities and typical skills required by a physicist who might be employed by them.

- Several articles have been published in Physikalische Blätter on the workgroup's activities. These articles also serve as an outlet to initiate new ideas in the community and for feedback on experience gained in the sector of interest.

\section{Data acquisition}

Detailed opinion polls evaluating the professional and social situation of graduates have been carried out and published by members of the workgroup. Data analysis helps find new focal points for the workgroup's activities. It also provides feedback regarding the effectiveness of past actions.

5. Improving the sense of responsiblity of young graduates at universities

- A series of letters to all Deans of physics in Germany describes the present situation and asks for feedback concerning actions which have already been under- taken by the faculties. The aim is to encourage those activities which help to inform and prepare physics students and graduates for the growing demands of the job market.

- Permanent contacts to the national organization of physics students' representatives (ZAPF) have been established. This forum has produced a checklist for students to be handed out after two years of study. The checklist aims to improve students' awareness of the need to take an independent, immediate initiative.

At the EPS General Conference (EPS10), held in Seville in September 1996, a symposium on the status quo and trends of the physics job market situation in different countries was organized. Young physicists from Austria, Finland, Germany, Italy, the United Kingdom, and the Ukraine prepared surveys of their respective national situation which were presented and discussed. The participants agreed to call for improved, stronger international contact between groups such as the AKO.

The AKO aims to hold a meeting at CERN this year, intending to exchange ideas with the invited representatives of similar organizations across Europe (e.g. Association-Bernard-Gregory, France, APS etc.). Relevant achievement and experience already gained shall be evaluated.

Current information about the committee and its activities can be accessed by WWW: http://www.uniulm.de/ uni/intgruppen/dpg-ako/ako-home.htm

Stefan Kubsky, Ruhr-Universität Bochum

\section{References:}

[1] Röhrich K., Wirth H., "Einstieg ins Berufsleben (Umfrage)" Phys. Bl. 53 (1997), Nr. 1, 50

[2] Becker H., Kleef J., "Arbeitskreis Optionen

für die Zukunft" Phys.Bl. 52 (1996), Nr. 7-8, 680 [3] Nestle N., "Von 'realitätsfernen Doktorvätern' und 'wenig idealistischen Doktoranden' (Umfrage)" Phys. Bl. 52 (1996), Nr.7, 658 [4] Reineker P., "Statistiken zum Physikstudium in Deutschland" Phys. Bl. 52 (1996), Nr. 9, 893 [5] Sixl H., "Arbeitsmarkt für Physiker: Situationsbericht 1995" Phys. Bl. 52 (1996), Nr. 9, 980

\section{Contact address:}

Stefan Kubsky

Ruhr-Universität Bochum, Lehrstuhl für Experimentalphysik III, Gebäude NB 3/69

D-44780 Bochum

Tel: $+492347006919 / 3594$

Fax: +492347094172 